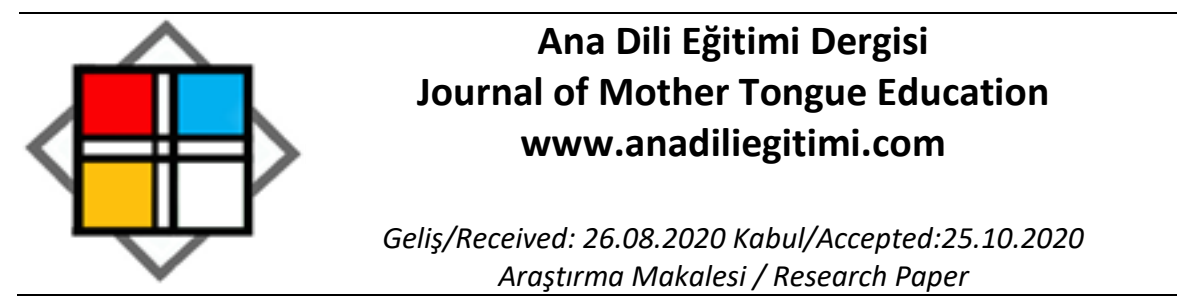

\title{
Erken Çocukluk Eğitimi Öğretmenlerinin Hikâye Anlatma/Kitap Okuma Uygulamaları Tercihleri ve Nedenleri
}

\author{
Nesrin IŞIKOĞLU ERDOĞAN* \\ Zeynep Ceren ŞIMŞEK ${ }^{* *}$
}

\begin{abstract}
Öz
Bu araştırmanın amacı erken çocukluk eğitimi öğretmenlerinin Türkçe etkinliklerinde kullandıkları ve tercih ettikleri kitap okuma/hikâye anlatma tekniklerini belirlemek ve bu tekniklerin tercih nedenlerini incelemektir. Temel nitel araştırma deseninin kullanıldığı bu araştırmaya erken çocukluk eğitim kurumlarında çalışmakta olan 91 okul öncesi öğretmeni katılmıştır. Veriler sıralama yargılarına dayalı olarak geliştirilen 'Hikâye anlatma ve kitap okuma formu' aracılı̆ııyla toplanmış ve içerik analizi kullanılarak analiz edilmiştir. Araştırma bulguları öğretmenlerin sınıflarında en fazla geleneksel okumayı, en az dijital okumayı uyguladıklarını, çocukların en fazla dijital okumayı tercih ettiklerini ve etkileşimli okumanın ise en fazla öğrenmeyi destekleyen teknik olduğunu ortaya koymuştur. Hikâye anlatma teknikleri ile ilgili bulgular ise öğretmenlerin ve çocukların kuklalarla anlatımı daha çok tercih ettiklerini ancak yine de öğretmenlerin sınıf uygulamalarında en sık sesli (araçsız) anlatıma yer verdiğini göstermiştir. Öğretmenlerin tercihlerini tekniklerin hızlı, kolay, ekonomik olması ve çok fazla ön hazırlık gerektirmemesi gibi nedenlerin etkilediği belirlenmiştir.

Anahtar Kelimeler: Erken çocukluk eğitimi, Hikâye anlatma, Kitap okuma, Teknikler
\end{abstract}

\section{Early Childhood Education Teachers' Storytelling and Reading Practice Preferences and their Reasons}

\begin{abstract}
This study aims to examine the book reading and storytelling techniques that early childhood education teachers use and prefer in their Turkish language activities and their preference reasons. The participants of this basic qualitative study were ninety-one early childhood teachers who currently work in classrooms. The data were collected through the 'Storytelling and Book Reading Form' developed based on ranking judgments and analyzed using content analysis. Research findings revealed that teachers used traditional reading the most and digital reading the least in their classrooms and that children preferred digital reading the most and interactive reading was the technique that supported learning the most. Regarding storytelling techniques, the research results showed that the teachers mostly told stories using their voices (without any outside tools), and that the teachers and children preferred storytelling with puppets the most. Being fast, easy, and economical and not requiring too much preparation were among the reasons that affected teachers' preferences in selecting and using a technique.
\end{abstract}

.Keywords: Early childhood Education, Storytelling, Book reading, Techniques

\section{Giriş}

Dil bireyler arası iletişimde kullanılan semboller sistemi olarak tanımlanan, nispeten karmaşık bir yapıda yer alan kodlardan oluşur. Dil sayesinde nesiller; fikirlerini, duygularını ve hayal güçlerini ifade ederek; bilgilerini, deneyimlerini ve kültürlerini bir sonraki nesile aktarma imkânı bulur (Cohen, 2010; Owens 2012). Erken çocukluk eğitimi dönemi dil edinimi için kritik öneme sahiptir ve bu

\footnotetext{
${ }^{*}$ Prof. Dr., Pamukkale Üniversitesi, Denizli, nisikoglu@pau.edu.tr, Orcid ID: 0000-0001-7010-302X

${ }^{* *}$ Arş. Gör. Dr., Pamukkale Üniversitesi, Denizli, cyesilyurt@pau.edu.tr, Orcid ID: 0000-0002-6622-7289
} 
dönemde çocuklar belirli aşamalardan geçerek dillerini öğrenirler (Santrock, 2012). Bu aşamalardan geçerken biyolojik faktörler kadar çocukların yakın çevrelerindeki bireylerle olan nitelikli sözel etkileşimlerinin de büyük öneme sahip olduğu vurgulanmaktadır (Berk, 2013; Rudman ve Titjen, 2018). Çocuklara hikâye anlatma ve kitap okuma, dil gelişimini destekleyici olarak nitelikli etkileşim çerçevesinde en çok önerilen etkinliklerdendir (Whitehurst ve Lonigan, 2001).

Hikâye anlatma ve kitap okuma benzer uygulamalar olsa da farklı amaçları desteklemek için kullanılırlar ve birbirlerinden farklı teknikler olarak tanımlanırlar. Hikâye anlatma yazının ve kitapların olmadığı dönemlerden bu zamana kadar devam eden, geleneksel edebiyatın ya da kişisel öykülerin sözel olarak yorumlanması olarak tanımlanan kültürel bir mirastır (Brand ve Donato, 2001). Bununla birlikte, hikâye anlatımı yalnızca sosyal bir deneyim değil, aynı zamanda dil ediniminde etkili bir yapı taşı görevi gördüğü için okuryazarlığa geçişi de kolaylaştırmaktadır (Dyson ve Freedman, 1991). Yetişkinin sesi ve hareketleriyle çocuklara bir olay örüntüsünü ifade ettiği hikâye anlatımının çocukların yaratıcı düşünme becerilerini, sözcük dağarcığını, dinleme ve anlama becerilerini arttırdığı belirtilmektedir (Mayesky, 2008). Ayrıca hikâye anlatma; dilin nasıl çalıştı̆̆ını, hikâyelerin nasıl inşa edildiğini, karakterlerin nasıl geliştiğini, kelimelerle nasıl bir resim çizileceğini, problemlerin nasıl çözüleceğini ve karmaşık olayların nasıl örüleceğini modelleyerek çocukların daha iyi okurlar olmalarını, hikâyeyi anlama ve anlatma becerilerini geliştirmelerini de desteklemektedir (Isbell, Sobol, Lindauer ve Lowrance, 2004; Tompkins, 2003; Wright ve Dunsmuir, 2019). Erken çocukluk döneminde hikâye anlatımında farklı teknikler kullanılmaktadır. Hikâyenin yalnızca anlatıcının ses ve mimikleriyle ifade edildiği geleneksel (araçsız) hikâye anlatımı, anlatıcının aksesuar ya da kostüm kullanarak bir karakter üzerinden hikâyeyi canlandırdığı bir karaktere bürünerek anlatım, hikâyenin ses olmadan yalnızca bedensel hareketlerle ifade edildiği pandomim, kuklalar ve kukla sahnesi kullanılarak yapılan anlatım, çeşitli tekniklerle hazırlanmıs hikâye kartlarından yararlanılarak anlatım ve pazen mıknatıslı veya mantar panolara yapıştırılan figürler kullanılarak anlatım gibi teknikler; hikâye anlatımını zenginleştirirken çocukların bireysel farklılıklarına göre öğrenmelerini de desteklemektedir (Işıkoğlu Erdoğan, 2016). Örneğin kuklalarla hikâye anlatımı çocuğu daha çok konuşmaya teşvik ederek ifade edici dil becerilerini desteklerken; geleneksel hikâye anlatımı ise çocukların alıcı dil becerilerinin gelişimini desteklemektedir. Varol, Âlâ ve Eti (2020), hikâye anlatım tekniklerinin çocukların dikkat süresi üzerine etkisini inceledikleri araştırmalarında; farklı teknikler kullanmanın göz teması kurma, dikkati canlı tutma, odaklanma, başlığı ve kahramanları hatırlama, sorulara cevap verme gibi adımlarda farklı sonuçlar verdiğini bulmuşlardır.

Okuma bilen yetişkinin okuma bilmeyen çocuğa yazılı bir materyalden genellikle çocuk edebiyatı ürünlerinden faydalanarak okuma yapması olarak tanımlanan kitap okuma (Hindman, Skibbe ve Foster, 2014); çocukların yeni kelime ve cümle yapıları ile karşılaşmasını sağlamakta, çeşitli bilgi ve kavramları öğrenmelerini kolaylaştırarak dil edinim becerilerini de arttırmaktadır (Martini ve Senechal, 2012). Yine bu dönemde çocuklara kitap okumanın en önemli faydalarından biri kitapların çocukta okuma yazma farkındalığı oluşturmasıdır (Wesseling, Christmann ve Lachmann, 2017). Okuma yazma becerilerinin resimli kitap okumayla arttığına ilişkin boylamsal çalışmalar; yazının soldan sağa ilerlediği, kelimelerin başlayıp bittiği, çeşitli harflerin çeşitli sesleri içerdiği gibi yazı farkındalı̆ıını pekiştiren becerilerin bu dönemde kitap okuma etkinlikleri aracılığıyla geliştiğini göstermektedir (Bus, Belsky, Van IJzendoorn ve Crnic, 1997; Lonigan ve Whitehurst, 1998; Saracho ve Spodek, 2010; Senechal ve LeFevre, 2002). Ek olarak erken yaşta nitelikli çocuk edebiyatı ürünleri ile tanışmanın çocukların yaratıcılık becerileri desteklediği, eleştirel düşünme becerileri arttırdığı ve kitaptaki karakterlerle empati kurma yoluyla sorumluluk bilincini geliştirdiği de araştırmalarla desteklenmektedir (Masataka, 2014; Morgan, 2013). Alan yazında kitap okumanın dil gelişimiyle olan etkisini inceleyen araştırmalar; hangi kitabın okunduğu, kitabı kimin okuduğu, nasıl okuduğu, kitap okunan gruptaki çocuk sayısı ve yetişkinin kitabı okurken uyguladığı tekniklerin okumanın etkisini azaltmakta ya da arttırmakta olduğunu göstermiştir (Marulis ve Neuman, 2013, Wasik, Hindman ve Snell, 2016). Erken dönemdeki çocuklar kitaplar aracılığıyla dünyayı anlamlandırdığı için okunacak kitapların, çocukların sadece keyifli zaman geçirmesi açısından değil, aynı zamanda; sosyal, duygusal ve bilişsel gelişim açısından da çocuğu destekleyecek nitelikte olmasına dikkat edilmelidir. Kitaplarda kurgulanan hikâyelerin okuma sonrasında çocuğun kendi gerçekliğine yerleştirebileceği hikâyeler olması ve çocukla gerçek yaşam 
arasında bir köprü görevi görmesi gerekmektedir (Akın, 1998; Şimşek, 2017). Çocuğa sunulan kitapların içerik olarak çocuğun yaş grubuna uygun olması, yazım dilinin sade ve anlaşılır olması, sık diyaloglar ve kısa paragraflara yer verilmesi ve görsel olarak yazılı metni destekleyerek yeni kavram ve kelimeleri somutlaştırması çocuk kitaplarının niteliğini arttıran ve çeşitli okuma tekniklerine de zemin hazırlayan özelliklerdendir (Şirin, 2000).

Erken çocukluk döneminde çocuklara kitap okumak için farklı teknikler kullanılmaktadır (Gonzalez, Taylor, Davis ve Kim, 2013; Hindman, Skibbe ve Foster, 2014). Örneğin sıklıkla kullanılan tekniklerden biri olan geleneksel (sesli) okuma; okuma bilen bir yetişkin tarafından okuma bilmeyen bir çocuğa metnin/kitabın bölünmeden aktarılması olarak tanımlanır. Bu okuma tekniğinde okuyucu dinleyici ile herhangi bir diyaloğa girmeden ve okuma eyleminin akışını bölmeden metni seslendirir. Okuyucunun dinleyici ile sorular ve tanımlar üzerinden etkileşime girerek karşııklı iletişim halinde kitabı aktardığı ve kitap hakkında belirli noktalara vurgu yaparak kitabı seslendirdiği okuma tekniğine ise etkileşimli okuma adı verilir. Erken çocukluk döneminde kullanılan bir diğer teknik ise elektronik okumadır. Kitapların sesli ve görüntülü olarak dijital ortama aktarılması ya da doğrudan dijital ortamda kitap biçiminde yazılmış olan resimli dijital içeriklerin çocuklara sunulmasına elektronik okuma adı verilir. Bu teknik kullanılırken dikkat edilmesi gereken en önemli nokta çocuklar için hazırlanan dijital kitapların belirli bir hikâyesi olan ve okuma eylemini barındıran içerikler olması gerektiğidir. (Işıkoğlu Erdoğan, 2016).

Kitap okuma ve hikâye anlatımının çocuklara olan etkilerini karşılaştıran araştırmalar alan yazında sıklıkla yer almaktadır. Örneğin kitap okuma ve hikâye anlatmanın etkilerinin karşılaştırıldığı bir araştırmada, hikâye anlatma sırasında karşılıklı etkileşimin daha fazla olduğu bulunmuşken (Morrow, 2005); hikâyeyi dinleyen çocukların öyküyü daha iyi anladıkları tespit edilmiştir (Isbell, Sobol, Lindauer ve Lowrance, 2004; Zivan ve Kraus, 2020). Benzer şekilde geleneksel hikâye anlatımının, sesli okumaya kıyasla çocuklarda anlama ve kelime bilgisini artırdığı ve dikkat süresini geliştirdiği gösterilmiştir (Lenhart, Lenhard, Vaahtoranta ve Suggate, 2020; Trostle ve Hicks, 1998;). Hikâye okuma ve anlatmanın kelime öğrenmeye olan etkilerini karşılaştııılığı araştırmada 6 yaş çocuklarının kelime öğrenmelerinde dikkate değer farklar bulunmamıştır (Lenhart, Lenhard, Vaahtoranta, ve Suggate, 2018). Resimli kitap okuma ve hikâye anlatma deneyimi arasında 4-11 yaş çocukların beyin aktivitelerinin kaydedildiği araştırmalarında Yabe ve arkadaşları (2018) bilişsel gereklilik açısından önemli farklar olduğunu, prefrontal aktivasyondaki farkın hikâye anlatımında hayal etme eylemini gerçekleştirmek için gerekli bilişsel taleplerden kaynaklandığı belirtilmişlerdir.

Hikâye anlatma ve kitap okumanın çocuklara olan olumlu etkileri erken çocukluk eğitiminde bu etkinliklerin tercih edilmesini ve düzenli yapılan günlük Türkçe etkinlikleri içinde yer almasını sağlamıştır. Okul öncesi eğitim programı içerisinde (MEB, 2013) resimli kitap okuma, etkileşimli ve paylaşımlı okuma, öykü anlatma, tamamlama, tekrar anlatma, resimlendirme ve yeni bir öykü oluşturma gibi etkinliklerin yapılması önerilmektedir. Bununla beraber araştırmalar bu etkinliklerin nitelikleri ile ilgili bazı sorunlar ortaya koymaktadır. Dil etkinliklerine öğretmenlerin yeteri kadar süre ayırmadıkları ve ayırdıkları sürede ise sınırlı sözel etkileşimde bulundukları görülmektedir (Alışkan ve Güneyli, 2016; Gönen ve diğ., 2010; Işıkoğlu Erdoğan ve Akay, 2015). Öğretmenlerin gün içinde öğretime ayrılan sürenin yalnızca \%10'unu Türkçe etkinliklerine ayırdıkları (Alışkan ve Güneyli, 2016), dil etkinliklerine ayrılan sürenin yaklaşık günde 10-15 dakika olduğu (Gönen ve ark., 2011; Işıkoğlu Erdoğan ve ark., 2016) ve ayrılan bu sınırlı sürede daha çok geleneksel yöntemlerle etkinliklerin yürütüldüğü, etkileşimli okuma, soru-cevap, tartışma ve rol oynama gibi çalışmalara nispeten daha az yer verildiği belirtilmiştir (Işıkoğlu Erdoğan ve Akay, 2015; Zembat ve Zülfikar, 2006). Dil etkinlikleri sırasında açık uçlu sorulara, okuryazarlık, fonolojik farkındalık gibi becerileri desteklemeye yönelik çalışmalara sınırlı olarak yer verdikleri saptanmıştır (Bay ve Alisinanoğlu, 2012; Tepetaş Cengiz, 2015). Oysa ki farklı tekniklerle çocuklara hikâye ve masal anlatılması gerektiği (Türkben, 2018), hikâye anlatımının drama gibi canlandırmaya dayalı etkinliklerle birleştirilmesinin faydalı olacağına (Şahin, 2018) Türkçe etkinlikleri planlanırken farklı tekniklerin kullanılmasına (Taner Derman, Ergişi \& Şahin Zeteroğlu, 2019) dair öneriler bulunmaktadır. Diyaloğa dayalı ve dijital okuma gibi farklı tekniklerle kitap okumanın çocuğun dil gelişimini (Şimşek, 2017) ve dikkat sürelerini (Varol, Ala ve Eti, 2020) geleneksel okumaya göre daha fazla desteklediği ortaya konmuştur. Öte yandan, öğretmenlerin hikâye 
anlatma ve kitap okuma tekniklerine yönelik görüşleri ve günlük olarak bu etkinlikleri tercih durumlarını ortaya koyan araştırmalara alan yazında rastlanmamıştır. Erken çocukluk eğitimi öğretmenlerinin farklı hikâye anlatma ve okuma tekniklerine Türkçe etkinlikleri içinde yer vermeleri çocukların dil gelişimine ve okuryazarlık becerilerini olumlu etkilemektedir. Bu kapsamda bu araştırma ile öğretmenlerin Türkçe etkinliklerinde kullandıkları tekniklerin ve neden bu teknikleri tercih ettiklerinin belirlenmesi bu etkinliklerinin niteliğinin artırımasında yararlı olacaktır.

Bu araştırmanın temel amacı erken çocukluk eğitimi öğretmenlerinin Türkçe etkinliklerinde uyguladıkları ve tercih ettikleri kitap okuma/hikâye anlatma tekniklerini, bu tekniklerin tercih edilme ve edilmeme nedenlerini ortaya koymaktır. Bu amaç doğrultusunda aşağıdaki sorulara cevap aranmıştır:

1. Erken çocukluk eğitimi öğretmenleri Türkçe etkinliklerinde hangi hikâye anlatma/kitap okuma tekniklerini kullanırlar?

2. Erken çocukluk eğitimi öğretmenleri ve çocukları hikâye anlatma/okuma tekniklerinden hangilerini tercih eder?

3. Erken çocukluk eğitimi öğretmenlerinin hikâye anlatma/okuma tekniklerini hangi nedenlerden dolayı tercih ederler?

\section{Araştırmanın Modeli}

\section{Yöntem}

Erken çocukluk eğitimi öğretmenlerinin Türkçe etkinliklerinde kullandıkları ve tercih ettikleri hikâye anlatma ve kitap okuma tekniklerini inceleyen bu araştırmada temel nitel araştırma modeli kullanılmıştır. Temel nitel araştırma belirlenen problemlerin doğal ortamında gerçekçi ve bütüncül bir şekilde ele alınarak; gözlem, görüşme ve doküman analizi gibi nitel veri toplama teknikleri kullanılarak öznel bir yorumlama sürecinde incelenmesini ifade etmektedir (Meriam, 2009; Creswell, 1998; Lincoln ve Denzin, 1994). Eğitim gibi uygulamalı alanlarda sıklıkla kullanılan temel nitel araştırma anlamları ortaya çıkarmak ve yorumlamayı amaçlar (Meriam, 2009). Bu araştırmada öğretmenlerin hikâye anlatma ve kitap okuma tekniklerini uygulamaları, tercihleri ve bu tercihlerinin nedenleri incelenmiştir.

\section{Araştırma grubu}

Araştırmaya, ulaşılabilir örneklem yoluyla belirlenen, Türkiye genelinde çeşitli il ve ilçelerde görev yapan 91 erken çocukluk eğitimi öğretmeni katılmıştır. Katılımcı öğretmenlerin özellikleri incelendiğinde \%94,4'ünün ( $n=84)$ kadın ve \%5,6'sının $(n=7)$ erkeklerden oluştuğu görülmektedir. Çalışmaya katılan öğretmenlerin \%15,4'ü ( $n=14$ ) lisansüstü eğitim almıştır ve \%48'i $(n=51,1)$ ilkokul bünyesinde bulunan anaokullarında, $\% 47,2^{\prime} \mathrm{si}(n=43)$ ise bağımsız anaokullarında görev yapmaktadır. Katılımcı öğretmenlerin hizmet süreleri 1-5 yıl arası \%47,6 $(n=44), 6-10$ yıl arası \%34,5 $(n=32)$ ve 10 yıl ve üstü $\% 17,9(n=17)$ olarak belirlenmiştir. Araştırmaya katılan öğretmenlerin en büyük bölümü $\% 48,9$ ile 5 yaş grubuna $(n=44)$, kalanlar ise $6(n=22,1, \% 25)$ ve $4(n=26, \% 29)$ yaş gruplarına öğretmenlik yapmaktadır.

\section{Veri Toplama Araçları}

Veriler araştırmacılar tarafından geliştirilen "Hikâye Anlatma ve Kitap Okuma Formu" ile toplanmıştır. Formun ilk bölümü öğretmenlerin kişisel bilgilerinin sorulduğu 7 adet açık uçlu sorudan oluşmaktadır. İkinci bölümde öğretmenlerin genel olarak uyguladıkları ve tercih ettikleri hikâye anlatma ve okuma tekniklerini sıralamalarının istendiği 9 madde yer almıştır. Bu maddelerle öğretmenlere kitap okuma teknikleri -geleneksel, etkileşimli ve dijital kitap okuma- ve hikâye anlatma teknikleri -hikâye kartları, kuklalar, pazen tahta, pandomim- bir karaktere bürünerek ve sadece sesiyle (araçsız) anlatım- olarak toplam 9 okuma ve anlatma tekniği sunulmuş ve öğretmenlerden kendi tercihleri doğrultusunda 1-den 9-a kadar puanlamaları istenmiştir. Bu form bireylerin maddelerin tümünü görerek her bir maddeyi diğer maddelerle karşılaştırması ve bir sıra sayısı belirlemesi üzerine geliştirilmiştir (Güvendir ve Özkan, 2013; Turgut ve Baykul, 1992). Formda yer alan maddeler için; öğretmenlerin genel olarak tercih ettikleri, çocukların öğrenmesini desteklediğini düşündükleri ve çocukların en çok tercih ettikleri teknikler olarak ayrı ayrı sıralama yapmaları istenmiştir. Formun 
üçüncü bölümünde ise en çok ve az tercih ettikleri hikâye anlatma ve kitap okuma tekniklerinin ne olduğunu, neden bu tekniği tercih ettikleri veya etmediklerini açıklamalarının istendiği 4 adet açık uçlu soru sorulmuştur. Hazırlanan "Hikâye Anlatma ve Kitap Okuma Formu" okul öncesi eğitimi alanında uzman beş akademisyene uzman görüşü almak için gönderilmiştir. Formdaki sorular "Uygun", "Uygun değil" ve "Öneriler" olarak uzmanlarca değerlendirilmiş ve Miles ve Huberman'nın (1994) güvenirlik formülüne göre (Güvenirlik = Görüş Birliği/ (Görüş Birliği + Görüş Ayrılığı) formun güvenirliği 0,98 olarak hesaplanmıştır.

\section{Verilerin Toplanması}

Veri toplama aracı ve araştırmaya katılımı içim onam formu Google surveyden oluşturulmuştur. Ölçme aracının linki online olarak okul öncesi öğretmenlerinin bulunduğu çeşitli WhatsApp grupları, sosyal medya ağları ve eposta linkleri aracılığı ile paylaşılmıştır. Veri toplama aracı 2017 bahar öğretim yılında yaklaşık bir ay sürecinde çevrimiçi olarak yayınlanmış ve bir ay sonunda onam formu ve anketi eksiksiz dolduran öğretmenler araştırmaya dâhil edilmiştir.

\section{Verilerin Analizi}

Bu araştırma da elde edilen veriler içerik analizi yöntemiyle analiz edilmiştir. Elde edilen verilerde tekrar eden konular ve kavramların ayrıştıııması, sayılması ve yorumlanması olarak tanımlanan (Denzin ve Lincoln, 1998) içerik analizi ile erken çocukluk eğitimi öğretmenlerinin "Hikâye Anlatma ve Kitap Okuma Formuna" verdikleri cevaplar öncelikle tercih sıralama puanları olarak toplanmış ve ortalamaları hesaplanmıştır. Elde edilen toplamlara dayalı en çok ve en az tercih edilen teknikler belirlenmiştir ve bunlara dair grafik ve şekiller hazırlanmıştır. Formun üçüncü bölümünde yer alan açık uçlu sorulara öğretmenlerin verdikleri cevaplar ise iki araştırmacı tarafından okunmuş ve kodlanmıştır. Kodlayıcırlar arasındaki farklar tartışılarak uzlaşma sağlanmıştır. Daha sonra temalar oluşturularak bunları temsil eden alıntılar belirlenmiştir. Bu analiz süreci sonunda iki temel tema oluşturulmuştur. Bunlar (1) öğretmenlerin kullandıkları kitap okuma ve hikâye anlatma teknikleri ve bu teknikleri kullanma nedenleri (2) öğretmenlerin, çocukların tercih ettikleri ve öğrenmeyi desteklediklerine inandıkları tekniklerinin karşılaştırılması olarak adlandırılmıştır.

\section{İnandırıcılık ve Aktarılabilirlik}

Nitel araştırmalarda geçerlilik ve güvenirlilik kavramlarının yerine inandırıcılık ve aktarılabilirlik kavramları kullanılmaktadır (Lincoln ve Denzin, 1994; Merriam, 2009). Nitel araştırmalarda inandırıcılık ve aktarılabilirlik için derinlik odaklı veri toplama, çeşitleme, uzman incelemesi gibi çeşitli teknikler kullanılmaktadır (Merriam, 2009). Kullanılan görüşme formu alan uzmanlarından oluşan beş akademisyen tarafından incelenmiş ve onların görüşleri doğrultusunda yeniden düzenlenerek uzman incelenmesi gerçekleştirilmiştir. Bu araştırmada açık uçlu sorular ve doğrudan katılımcı ifadelerinin alıntılanmasıyla derinlik odaklı veriler elde edilmiş, iki farklı uzman tarafından veriler analiz edilerek araştırmacı üçgenlemesi sağlanmıştır.

\section{Etik Kurulu İzni}

Araştırma süreci boyunca araştırma ve yayın etiğine uyulmuştur. Bu amaçla katılımcıların gönüllü olmaları ve onam formu doldurmaları istenmiştir. Araştırmaya katılan öğretmenlerin tamamının yetişkindir ve kendi iradeleri ile gönüllü olarak araştırmaya katılmışlardır. Ayrıca, katılımcıların kimliklerini ortaya çıkaracak isimleri veya çalıştıkları okulun adı gibi sorulara yer verilmemiştir. Veriler 2020 yılından önce elde edildiği için etik kurul izni alınamamıştır.

\footnotetext{
Bulgular

Öğretmenlerin kullandıkları kitap okuma/hikâye anlatma teknikleri ve nedenleri

Katılımcı 91 öğretmene son bir ay içinde kullandıkları hikâye anlatma ve okuma tekniklerini kaç kez kullandıkları sorulmuş ve $0^{\prime}$ dan 10'a kadar derecelendirmeleri istenmiştir. Öğretmenlerin tekniklere verdikleri puanlar toplanmış, ortalamaları alınmış ve sonuçlar Şekil 1'de gösterilmiştir.
} 


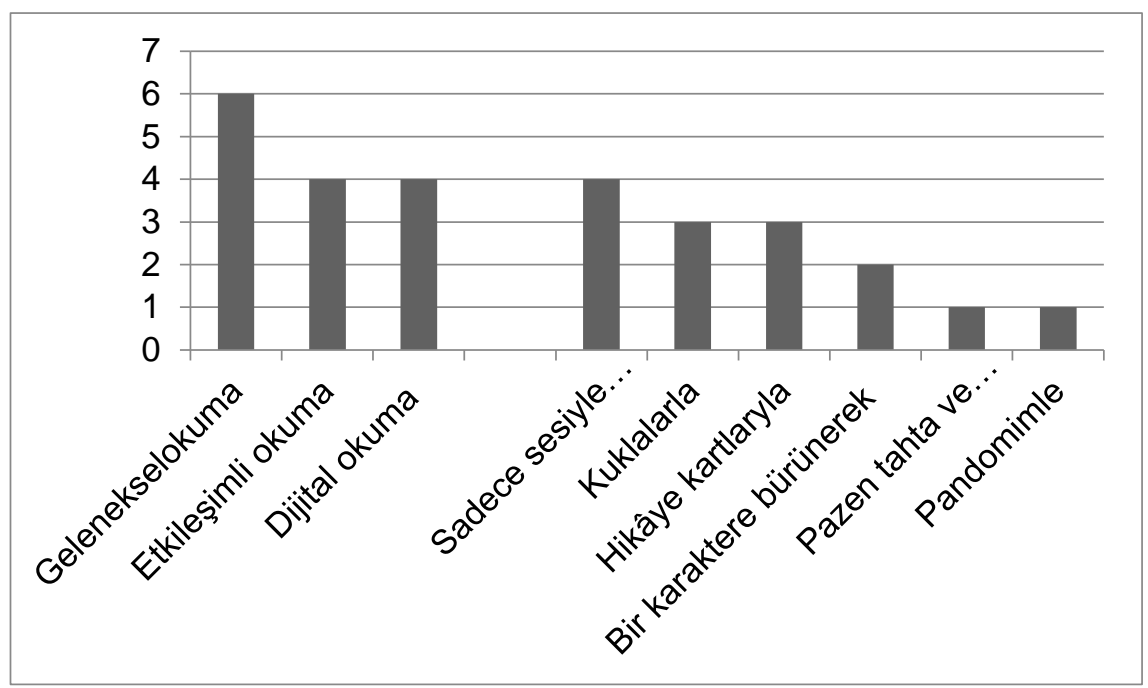

Şekil 1. Öğretmenlerin Kullandıkları Hikâye Anlatma ve Okuma Teknikleri

Öğretmenlerin son bir ayda gerçekleştirdikleri kitap okuma ve hikâye anlatma teknikleri incelendiğinde geleneksel okuma olarak tanımlanan resimli hikâye kitabını sınırlı sözel etkileşimle çocuklara doğrudan okunmasının en fazla tercih edilen okuma tekniği olduğu ve ayda ortalama 6 kez kullanıldığı saptanmıştır. Hikâye anlatma teknikleri incelendiğinde öğretmenin herhangi bir materyal kullanmadan sadece kendi sesiyle (araçsız) anlatmanın ayda ortalama 4 kez ile en fazla kullanılan teknik olduğu görülmüştür. Genel anlamda öğretmenler ayda 17 kez hikâye anlatma tekniklerini kullandıklarını ve 15 kez hikâye kitabı okuduklarını belirtmişlerdir. Bu sonuçta öğretmenlerin hikâye anlatma tekniklerini kitap okuma tekniklerinden daha fazla sıkıkta kullandıklarını göstermektedir.

Katılımcı öğretmenlerin bir tekniği diğerine göre neden daha fazla kullanıldığının sorulduğu açık uçlu sorular analiz edildiğinde ortaya çıkan kategori ve kodlar Şekil 2'de verilmiştir.

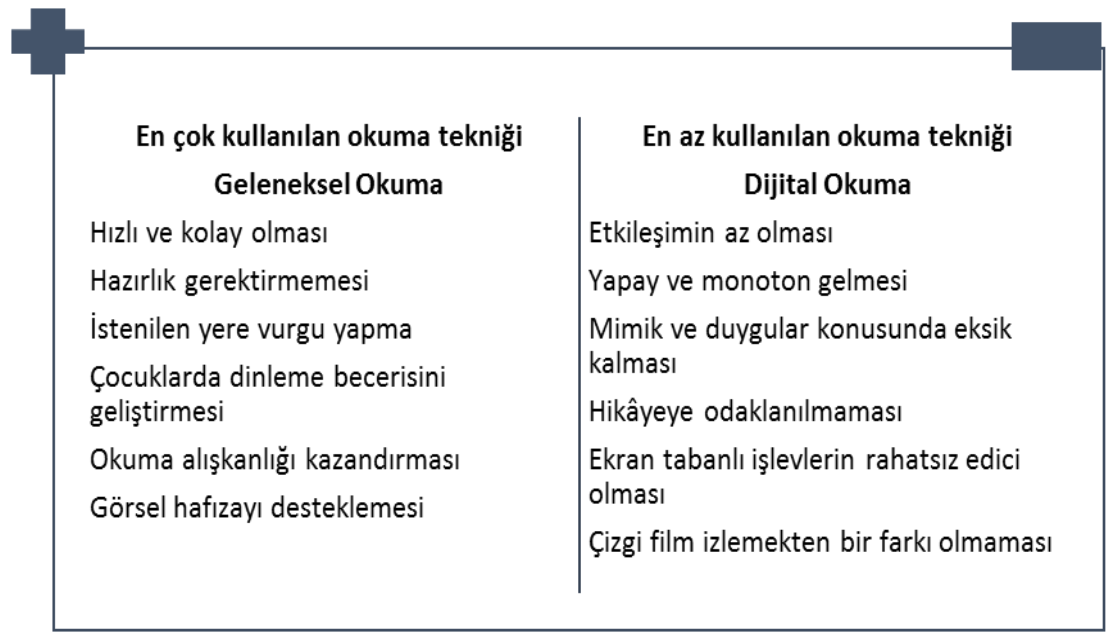

Şekil 2. En Çok, En Az Kullanılan Kitap Okuma Tekniklerinin Nedenleri

Yukarıdaki şekilde görüldüğü gibi katılımcı öğretmenlerin geleneksel okumayı kullanmalarının en önemli sebeplerinden biri bu tekniğin hızlı ve kolay uygulanması ve yoğun bir hazırlık gerektirmemesi olarak belirtilmiştir. Örneğin öğretmen 56 "Sesli hikâye okuma tekniğini seviyorum çünkü en hızlı ve kolay ulaşabildiğim bir teknik". Katılımcı öğretmenlerin birçoğu farklı teknikleri denerken sınıf mevcudunun fazlalığı sebebiyle sınıfa hâkim olamadıklarını ve çocukların ilgisinin çabuk dağıldığını ifade etmişlerdir. Geleneksel olarak resimli çocuk kitaplarından hikâye okumanın, çocukların görsel hafızasını desteklediğini, kalabalık gruplarda etkin dinleme sağladığını ve çocuğa erken okuma 
alışkanlığı kazandırdığını katılımcı öğretmenler dile getirmişlerdir. Öğretmen 63 ve 27 resimli kitap okumanın olumlu etkilerini aşağıdaki ifadeleriyle açıklamışlardır.

Resimli kitaplar hem ekonomik hem çok rahat. Çocukları kitaplara yaklaştırdığına, kitap okuma alışkanlığını kazandırdığı, davranış değişikliği yarattığını inanıyorum çünkü çocuk öğretmenini sürekli kitap okurken görüyor (Öğretmen 63).

Resimli kitapları okumayı seviyorum çünkü resimler öğrencilerin görsel hafızasını harekete geçiriyor ve hikâyeyi görsel olarak zihinlerinde daha iyi canlandırabiliyorlar (Öğretmen 27).

Benzer şekilde geleneksel okuma tekniğini diğer okuma teknikleri ile kıyaslayan öğretmenler; sınıf hâkimiyeti sağlamakta güçlük çektiklerini, diğer tekniklerin hikâyenin önüne geçtiğini ve çocukların hikâyenin ana fikrini kaçırdıkları şeklinde görüşlerini belirtmişlerdir.

Sesli kitap okuma tekniğini seviyorum çünkü öğrencilerimi tanıdığım için ses tonumu onların merakını canlı tutacak şekilde ayarlayarak hikâyeyi daha etkin dinlemelerini sağlayabiliyorum. Etkileşimli okumada çocuklar konuyu dağıtarak diğer arkadaşlarının hikâyeden uzaklaşmasına neden olabiliyor (Öğretmen 78).

Katılımcı öğretmenlerin en az uyguladıkları kitap okuma tekniği olarak dijital okuma belirlenmiştir. Özellikle dijital okuma tekniğinin, çocukları ekran tabanlı araçlara yönelttiği, bu tekniğin kitap okuma değil de çizgi film izleme gibi anlaşıldığı çin çocukların hikâyenin özünü kaçırdığını belirten öğretmenler aynı zamanda bu tekniğin çocuklar arasındaki grup içi etkileşimi kısıtladığını dile getirmişlerdir. Örneğin, Öğretmen 2 aşağıdaki ifadeleriyle dijital okumadan neden hoşlanmadığını belirtmiştir.

Çizgi filmmiş gibi izliyorlar, kitap okuma alışkanlığı kazandırmadığını düşünüyorum. Çünkü okuma alışkanlığı kazanmak için çocukların kitaplara dokunması sayfa kokuları duymasını ve o sayfa değiştirme sesini duymaları gerektiğini düşünüyorum.

Dijital okuma tekniğinin öğretmenler tarafından tercih edilmeme nedenleri arasında bu tekniğin çocukları pasifleştirdiği vurgulanmıştır. Öğretmen 92 "Dijital ortamda kitap okumayı sevmiyorum çünkü çocuklarla etkileşim olmuyor. Çocuklar pasif dinleyici oluyorlar. Her ne kadar farklı bir deneyim sunsa da kuzu kuzu dinlemekten öteye geçemiyorlar" ifadeleriyle bu tekniği kullanmaktan hoşlanmadığını söylemiştir.

Hikâye anlatma teknikleri ile ilgili tercih nedenleri incelendiğinde erken çocukluk eğitimi öğretmenlerinin en fazla araçsız hikâye anlatımı olarak açıklanan sadece kendi sesini kullanarak hikâye anlatımını, en az ise sözsüz anlatım olarak açıklanan pandomimi tercih ettikleri belirlenmiştir. Bu tekniklerin tercih nedenleri Şekil 3'te listelenmiştir.

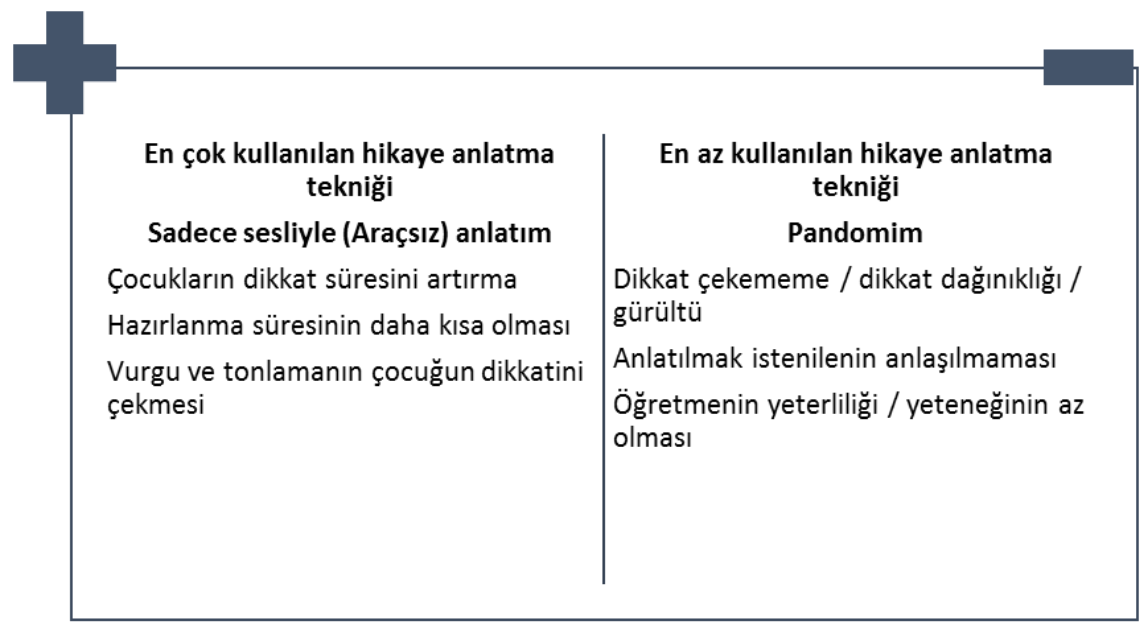

Şekil 3. En Çok, En Az Kullanılan Hikâye Anlatma Tekniklerinin Nedenleri 
Sadece sesiyle (araçsız) anlatım tekniğini tercih eden öğretmenler bu teknikle hikâye anlattıklarında çocukların daha kolay hikâyeye odaklandıklarını, hazırlık aşamasının kısa olmasının ve çocukların dikkat sürelerini artırmada etkili bir teknik olmasının araçsız anlatımı onlar için avantaja dönüştüğünü ifade etmişlerdir. Öğretmen 48 "Dikkatleri bende olup dinledikleri için bu tekniği kullanıyorum" derken, Öğretmen 66 "Hikâyeyi sesli olarak vurgu ve tonlamalarla anlatmak çocukların hayal gücünü geliştiriyor" ifadeleri ile araçsız anlatımın olumlu etkilerini dile getirmişlerdir. Bununla beraber öğretmenler pandomim tekniğini çok az kullandıklarını belirtmişlerdir. Bunun nedenleri arasında öğretmenin pandomim yapmak için eğitim alması gerektiğini, bu tekniği kullanırken kendilerini rahat hissetmediklerini, çocukların hikâyeyi anlamakta zorlandığını dile getirmişlerdir. Öğretmen 3 "Pandomim ile hikâye anlatma tekniğini sevmiyorum çünkü kendimi yeterli hissetmiyorum. Ayrıca çocuklar da ne anlatmak istediğimi anlamıyor" derken, Öğretmen 54 "Pandomim tekniğinden hoşlanmıyorum, çünkü sınıfım çok kalabalık ilgi ve dikkat dağılıyor" ifadeleri ile bu teknikten neden hoşlanmadığını belirtmiştir.

Öğretmenlerin, çocukların tercih ettikleri ve öğrenmeyi desteklediklerine inandıkları tekniklerin karşılaştırılması

Araştırmada öğretmenlere, çocukların en çok tercih ettiği ve çocukların öğrenmelerini en çok destekleyen kitap okuma ve hikâye anlatma tekniklerini en önemliden en az önemliye doğru $9^{\prime}$ lu derecelendirmeye göre sıralamalarının istendiği üç soru sorulmuştur. Bu sıralama sonucu kitap okuma teknikleri ile ilgili sonuçlar Şekil 4'de gösterilmiştir.

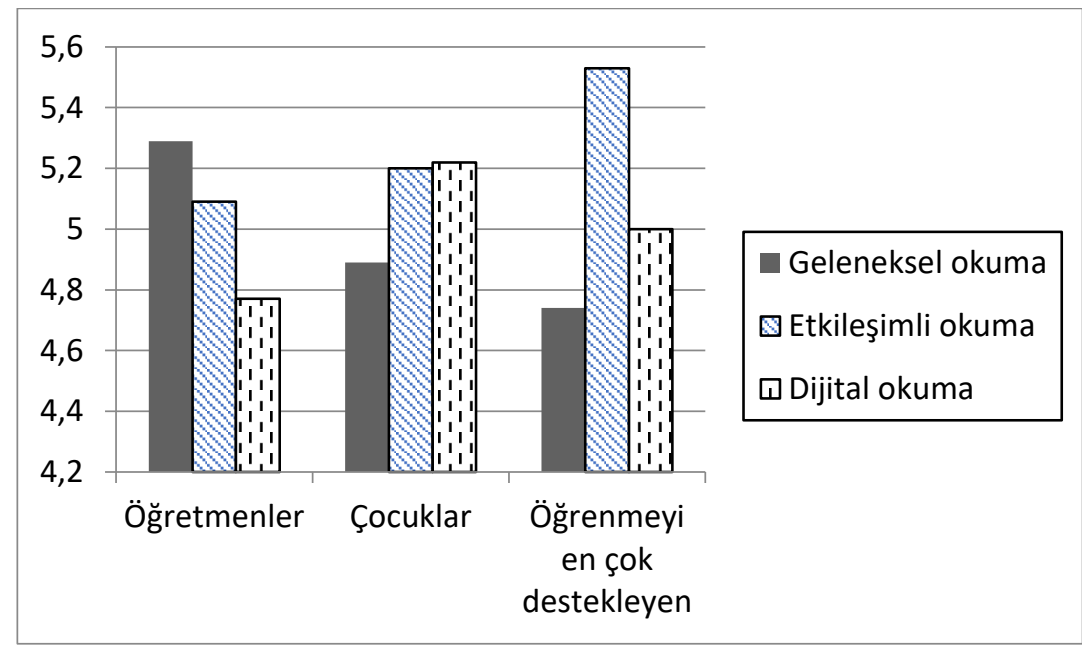

Şekil 4. Kitap Okuma Tekniklerinin Karşılaştııılması

Yukarıdaki sonuçlara göre erken çocukluk eğitimi öğretmenleri kitap okuma teknikleri arasında en sık geleneksel kitap okuma tekniğini $(\bar{x}=5.28)$, çocukların en çok dijital okumayı $(\bar{x}=5.22)$ tercih ederken, etkileşimli okumanın ( $\bar{x}=5.5)$ ise öğrenmeyi en çok destekleyen teknik olduğu ortaya çıkmıştır. Öğretmenlerin az tercih ettikleri okuma tekniği dijital okuma olurken $(\bar{x}=4.77)$ çocukların en az tercih ettikleri $(\bar{x}=4.89)$ ve öğrenmeyi en az desteklediği düşünülen $(\bar{x}=4.74)$ teknik geleneksel okuma olmuştur. Hikâye anlatma teknikleri ile ilgili tercih sıralama sonuçları hesaplanmış ve karşılaştırmalı olarak Şekil 5'te gösterilmiştir. 


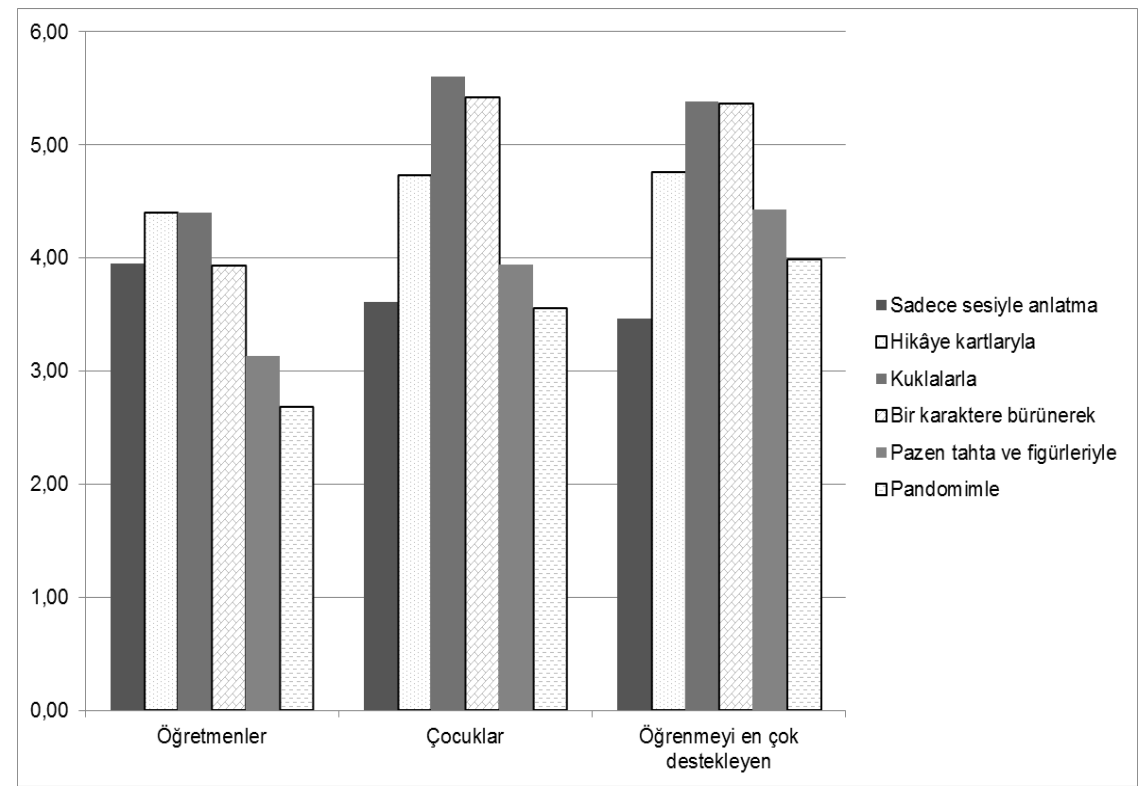

Şekil 5. Hikâye Anlatma Tekniklerinin Karşılaştırılması

Hikâye anlatma teknikleri ile ilgili araştırma sonuçlarına göre; erken çocukluk eğitimi öğretmenleri en fazla hikâye kartları ve kuklalarla anlatımı ( $\bar{x}=4.4)$ tercih ederken, çocukların en fazla kuklalar ile anlatım ( $\bar{x}=5.6$ ) ve bir karaktere bürünerek (masalcı nine, Süpermen, vb.) anlatımı $(\bar{x}=5.4)$ tercih ettikleri saptanmıştır. Öğrenmeyi en çok desteklediğine inandıkları hikâye anlatım tekniği olarak yine kuklalar $(\bar{x}=5.38)$ ve bir karaktere bürünerek anlatım $(\bar{x}=5.37)$ öne çıkmıştır. Aynı zamanda öğretmenler, çocukların en az tercih ettikleri ve öğrenmeyi en az destekleyen teknik olarak pandomim tekniğini belirtmişlerdir.

Tercih sonuçları karşılaştırıldığında; öğretmenler ile çocukların tercihleri ve çocukların öğrenmelerini en çok desteklediğini düşündükleri teknikler arasında farklılıklar görülmektedir. Kitap okuma tekniklerinde öğretmenler geleneksel okumayı daha fazla tercih ederken, çocukların ise kendilerinin okuma sürecinde daha aktif olabildikleri etkileşimli okumayı tercih ettikleri belirtilmiştir. Benzer şekilde öğretmenler geleneksel okumayı son bir ayda en fazla kullandıklarını ve tercih ettiklerini ifade ederken, çocukların öğrenmelerini en çok etkileşimli okumanın desteklediğini belirtmişlerdir. Bu sonuç öğretmenlerin kullandıkları okuma teknikleri ile çocukların tercihleri ve çocuklarının öğrenmesini desteklediğini düşündükleri teknikler arasında çelişkiyi ortaya koymaktadır.

Hikâye anlatma teknikleri arasında kuklalar çocuk, öğretmen tercihleri ve çocukların öğrenmelerini destekleyen teknikler arasında öne çıkmıştır. Katılımcı öğretmenler kuklalarla hikâye anlatımı ile ilgili olumlu tercihlerde daha fazla bulurken, son bir ayda sınıflarında kullandıkları teknikler arasında kuklalarla hikâye anlatımı üçüncü sırada yer almıştır. Bu sonuçta yine öğretmenlerin tercihleri ve uygulamaları arasında farklar olduğunu göstermektedir. Dikkat çekici bir diğer fark ise, katılımcı öğretmenlerin sadece sesini kullanarak (araçsız) anlatma tekniği ile ilişkili düşünceleri ve uygulamaları arasındaki farka yöneliktir. Öğretmenler araçsız anlatımın çocukların öğrenmelerini en az destekleyen teknik olduğunu ve aynı zamanda çocukların bu tekniği tercih etmediklerini belirtirken, son bir ayda en fazla araçsız anlatımı kullandıklarını işaret etmişlerdir. Pandomim tekniği ise tutarlı bir şekilde öğretmen ve çocuk tercihlerinde, öğrenmeyi desteklemede ve son bir ayda en az kullanılan teknik olarak belirtilmiştir.

\section{Tartışma ve Sonuç}

Erken çocukluk eğitimi öğretmenlerinin kitap okuma ve hikâye anlatma tekniklerine yönelik uygulamaları, tercihleri ve bunların nedenlerinin incelendiği bu araştırma önemli sonuçlar ortaya koymuştur. illk olarak öğretmenlerin Türkçe etkinliklerinde geleneksel okuma ve sadece sesiyle (araçsız) anlatım tekniklerini diğer tekniklerden daha fazla sıklıkla uyguladıkları saptanmıştır. Benzer araştırma sonuçları erken çocukluk eğitimi öğretmenleri dil etkinliklerinde en çok resimli kitaplardan 
faydalandıklarını göstermektedir (Gönen ve diğ., 2010). Geleneksel okuma ve sadece sesiyle (araçsız) anlatımın daha fazla tercih edilmesinde bu tekniklerin hızlı, kolay, ekonomik olması ve çok fazla ön hazırlık gerektirmemesi gibi nedenler bulunmaktadır. Öğretmenler geleneksel okuma için hazırlıksız olsalar bile sınıflarında ya da okullarında bulunan kitaplardan faydalandıklarını, her iki teknikte de büyük gruplarda uygulanırken bile dikkatin dağılması ve gürültü gibi olumsuzluklardan kaçınabildiklerini belirtmişlerdir. Ayrıca bu tekniklerin uygulanmasının yaş grubuyla da doğrudan ilişkili olduğunu belirten öğretmenler küçük yaş gruplarının mutlaka görsel olarak desteklenmesinin önemli olduğunu ve dikkat sürelerinin materyalsiz etkinlikler için kısıtlı olduğunu vurgulamışlardır. Öğretmenlerin sıklıkla uyguladıklarını belirttikleri bu tekniklerin çocukları kendini ifade etmeye yönlendirmeden yalnızca dinlemeye yönelttikleri için, gelişim ve öğrenmeyi desteklemede çeşitli sınırlılıkları olduğu bilinmektedir (Hargrave ve Sénéchal, 2000; Şimşek, 2017; Whitehurst ve ark., 1994). Bu nedenlerle Türkçe etkinliklerinde öğretmenlerin farklı kitap okuma ve hikâye anlatma teknikleri dengeli kullanmaları önerilmektedir.

İkinci olarak araştırma sonuçları öğretmenlerin etkileşimli ve dijital kitap okumayı daha az sıklıkla uyguladıklarını ve tercih ettiklerini ortaya koymuştur. Güncel araştırmalar özellikle etkileşimli ve diyaloğa dayalı okuma gibi çocukların daha aktif katıldıkları okuma tekniklerinin geleneksel okumaya kıyasla alıcı ve ifade edici dil gelişiminde (Kotaman, 2008; Şimşek, 2017; Tetik ve Işıkoğlu Erdoğan, 2017) avantajlar sağladığını göstermektedir. Bu sebeple diyaloğa dayalı okumanın çocukların ifade edici dil gelişimleri üzerindeki etkisini desteklemek amacıyla öğretmenlerin diyaloğa dayalı okuma adımlarını öğrenmesi, yalnızca kitap okuma zamanında değil gün içerisinde çeşitli zaman dilimlerinde küçük gruplarla daha fazla uygulama yapılması önerilmektedir. Aynı şekilde dijital okumanın; okuryazarlık becerilerini, kelime öğrenmeyi (Roskos, Sullivan, Simpson, ve Zuzolo, 2016) ve hikâyeyi anlamayı desteklediğini (Reich, Yau, Xu, Muskat, Uvalle, ve Cannata, 2019) vurgulamaktadır. Dijital okumanın, çocukların hikâye anlatımı için kendi kapasitelerini kullanmalarını, okuryazarlık uygulamalarına katılmalarını ve diğer bireylerle etkileşimleri güçlendirdiği belirtilmiştir (Blackwell, Wartella, Lauricella ve Robb, 2015; Robin, 2008; Flewitt, Messer ve Kucirkova, 2015). Bununla beraber, bu araştırmada öğretmenlerin dijital okumayı "çizgi film izlemek" gibi değerlendirdikleri ve bu nedenle daha az sıklıkla kullandıkları bulunmuştur. Bu bağlamda erken çocukluk eğitimi öğretmenlerin dijital okuma ile ilgili bilgi ve deneyimlerinin artırılması önerilmektedir. Özellikle çocukların en fazla dijital okumayı tercih ettikleri sonucunu göz önüne alındığında öğretmenlerin etkileşimli medya araçlarını sınıflarında bulundurmaları, elektronik okumanın öncesinde ve sonrasında etkileşimli sohbet fırsatları yaratarak çocukları desteklemeleri ve dijital okumaya karşı daha olumlu tutum ve beceri geliştirmeleri yararlı olacaktır.

Araştırmanın ortaya koyduğu üçüncü sonuç öğretmenlerin sınıflarında uyguladıkları, kendilerinin ve çocukların tercih ettikleri, çocukların öğrenmesini en çok desteklediğini düşündükleri teknikler arasında tutarsızlıklar bulunduğudur. Bu tutarsızlıkların ortaya çıktığı tekniklerden biri olan etkileşimli okuma öğrenmeyi en çok desteklediğine inanılan ve çocuklarında sıklıkla tercih ettiği bir okuma tekniği olarak belirtilirken, öğretmen uygulama ve tercihlerinde daha az sıklıkla yer almıştır. Benzer bir tutarsızlık ise kuklalarla hikâye anlatma tekniğinde saptanmıştır. Erken çocukluk eğitimi öğretmenlerin benimsedikleri yaklaşımlarla uygulamaları arasındaki tutarlıı̆ı̆ incelendiği araştırmalarda öğrenci merkezli eğitim (Sak, Tantekin-Erden ve Morrison, 2017) ve gelişime uygun sınıf yönetiminde (Şahin-Sak, Tantekin-Erden ve Pollard-Durodola, 2018) farklılıklar bulunmuş ve bu farkların okullardaki fiziksel olanaklar ve çocukların özelliklerinden kaynaklanmış olabileceği vurgulanmıştır. Bu araştırmada öğretmenlerin, uygulamalarında daha fazla kullanılan geleneksel okuma ve araçsız anlatım tekniklerinin kolaylıkla, hızlıca ve büyük grupla uygulanabilme imkânı sağlayan teknikler olduğu vurgulanmıştır. Öte yandan, çocukların farklı okuma ve anlatma tekniklerinden farklı kazanımlar elde edeceği düşünüldüğünde çocukların daha fazla aktif katılım sağlayabilecekleri etkileşimli okuma, pandomim, pazen tahta ve figürleriyle anlatım gibi tekniklerine daha sıklıkla yer verilmesi önerilmektedir (Bıçakçı, Er ve Aral, 2018; Dereobalı ve Özcan, 2019; Işıkoğlu Erdoğan vd., 2016; Tepetaş Cengiz ve Gönen, 2018). Araştırmaya katılan öğretmenler bu teknikleri uygularken sınıf yönetimi zorlukları yaşadıklarını, özellikle pandomim ya da bir karaktere bürünerek anlatma gibi canlandırmaya dayalı tekniklerin uygulanması sırasında özel bir eğitim almadıkları için 
kendilerini yetersiz hissettiklerini ve bu sebeplerle sınıfın kontrolünü kaybettiklerini dile getirmişlerdir. Bu nedenle erken çocukluk eğitimi öğretmenlerinin hikâye okuma ve anlatma tekniklerini daha iyi kullanmalarını öğreten uygulamalı eğitimlere katılmaları yararlı olacaktır.

Hikâye okuma ve anlatma tekniklerine odaklanan bu araştırmanın sonuçları çalışmanın sınırılıkları ile birlikte değerlendirilmelidir. Öncelikle temel nitel araştırma deseninde gerçekleştirilen çalışmada olanaksılıklar nedeniyle veri çeşitlemesine gidilememiştir. Gelecekte yapılacak araştırmalarda Türkçe etkinliklerinin sınıf içinde gözlenmesi yoluyla veriler zenginleştirilebilir. Sınıf içi etkinliklerin doğrudan gözlenmesi ile elde edilecek verilerin öğretmenlerin uygulamalarında ve tercihlerindeki tutarsızlıkları belirginleştireceği düşünülmektedir.

\section{Kaynaklar}

Akın, N. (1998). Okul Öncesi Kurum Öğretmenlerinin Çocuk Kitaplarına Karşı Tutum ve Davranışlarııın incelenmesi (Yayımlanmamış doktora tezi). Hacettepe Üniversitesi Sağlık Bilimleri Enstitüsü, Ankara.

Alışkan, E. E., \& Güneyli, A. (2016). Okul öncesi öğretmenlerinin Türkçe dil etkinliklerine ilişkin görüşleri: Lefkoşa örneği. Ana Dili Eğitimi Dergisi, 4(3), 348-371.

Bay, D. N., \& Alisinanoğlu, F. (2012). Soru sorma becerisi öğretiminin okul öncesi öğretmenlerinin sorularının yapısı üzerine etkisi. Kuramsal Eğitimbilim Dergisi, 6(1), 1-39.

Berk, L. E. (2013). Bebekler ve çocuklar doğum öncesinden orta çocukluğa. (N. Işıkoğlu Erdoğan, Çev.). Ankara: Nobel Akademik Yayıncılık Eğitim Danışmanlık.

Bıçakçı, M. Y., Er, S. \& Aral, N. (2018). Etkileşimli öykü kitabı okuma sürecinin çocukların dil gelişimi üzerine etkisi. Kastamonu Eğitim Dergisi, 26(1), 201-208.

Blackwell C. K., Wartella E., Lauricella A. R., Robb M. (2015). Technology in the lives of educators and early childhood programs: trends in access, use and professional development from 2012 to 2014. Evanston, IL: Center on Media and Human Development at Northwestern University.

Brand, S.L. Trostle, \& J. M. Donato. 2001. Storytelling in emergent literacy: Fostering multiple intelligences. Wadsworth Publishing Company, Albany, NY: Delmar.

Bus, A. G., Belsky, J., Van ljzendoom, M. H., \& Crnic, K. (1997). Attachment and bookreading patterns: A study of mothers, fathers, and their toddlers. Early Childhood Research Quarterly, 12(1), 8198.

Cengiz, G. Ş., \& Gönen, M. (2018). An Investigation of the relationship between preschool teachers' picture story book reading activities and children's language development. In Buğa, D., \& Coşgun Ögeyik, M. (Ed.), Psycholinguistics and Cognition in Language Processing (pp. 188-220). IGI Global.

Cohen, N. J. (2010). The impact of language development on the psychosocial and emotional development of young chidren. In S. Rvachew (Ed.), Language Development and Literacy.

Creswell, J.W. (1998) Qualitative Inquiry and research design: Choosing among five traditions. Thousand Oaks, CA: Sage Publications.

Dereobalı, N., \& Özcan, M. (2019). Surprise box stories told by preschool children. Kastamonu Eğitim Dergisi, 27(5), 1865-1874.

Dyson, A. H., \& Freedman, S. W. (1991). Handbook of research on teaching english language arts writing. In J. Flood, J. M. Jensen, D. Lapp, \& J. R. Squire (Eds.). New York: Macmillan.

Flewitt, R., Messer, D., \& Kucirkova, N. (2015). New directions for early literacy in a digital age: The iPad. Journal of Early Childhood Literacy, 15(3), 289-310.

Gonzalez, J. E., Taylor, A.B., Davis, M. J. \& Kim, M. (2013) Exploring the underlying factor structure of the parent reading belief inventory (PRBI): Some Caveats. Early Education and Development, 24 (2), 123-137.

Gönen, M., Ünüvar, P., Bıçakçı, M., Koçyiğit, S., Yazıcı, Z., Orçan, M., Aslan, D., Güven, G. ve Özyürek A. (2010). Okul öncesi eğitim öğretmenlerinin dil etkinliklerini uygulama biçimlerinin incelenmesi. Mehmet Akif Ersoy Üniversitesi Eğitim Fakültesi Dergisi, (19), 23-40.

Güvendir, M. A., \& Özkan, Y. Ö. (2013). İki ölçekleme yönteminin karşılaştırılması: íkili karşılaştırma ve sıralama yargıları. Eğitim Bilimleri Araştırmaları Dergisi, 3(1), 105-119. 
Hargrave, A. C.; Sénéchal, M. (2000). A book reading intervention with preschool children who have limited vocabularies: The benefits of regular reading and dialogic reading. Early Childhood Research Quarterly, 15 (1), 75-90.

Hindman, A. H., Skibbe, L. E., \& Foster, T. D. (2014). Exploring the variety of parental talk during shared book reading and its contributions to preschool language and literacy: Evidence from the Early Childhood Longitudinal Study-Birth Cohort. Reading and Writing, 27(2), 287-313.

Isbell, R. Sobol, J. Lindauer, L. and Lowrance, A. (2004). The effects of storytelling and story reading on the oral language complexity and story comprehension of young children. Early Childhood Education Journal. 32(3), 157-163.

Işıkoğlu, Erdoğan, N. (2016) Edebiyat uygulamaları, çocuk edebiyatı ve medya. In S. Erdogan ve M. Ören (Eds) Çocuk edebiyatı. Açık Öğretim Yayınları: Eskişehir.

Işıkoğlu Erdoğan, N., \& Akay, B. (2015). Okul öncesi eğitimde hikâye okuma ve öğretmen sorularının incelenmesi. Mehmet Akif Ersoy Üniversitesi Eğitim Fakültesi Dergisi, 1(36), 34-46.

Işıkoğlu Erdoğan, N., Atan, A., Asar, H., Mumcular, F., Yüce, A., Kıraç, M., \& Kilimlioğlu, Ç. (2016). Ebeveyn ve öğretmenlerin birlikte hikâye okuma etkinliklerinin incelenmesi. ilköğretim Online, 15(1), 125-135.

Kotaman, H. (2008). Impacts of dialogical storybook reading on young children's reading attitudes and vocabulary development. Reading Improvement, 45(2), 55-61.

Lenhart, J., Lenhard, W., Vaahtoranta, E. \& Suggate, S. (2018) Incidental vocabulary acquisition from listening to stories: a comparison between read-aloud and free storytelling approaches. Educational Psychology, 38:5, 596-616,

Lenhart, J., Lenhard, W., Vaahtoranta, E., \& Suggate, S. (2020). More than words: Narrator engagement during storytelling increases children's word learning, story comprehension, and on-task behavior. Early Childhood Research Quarterly, 51, 338-351.

Lincoln, Y.S. \& Denzin, N.K. (1994). Handbook of qualitative research. CA: Sage.

Lonigan, C. J., \& Whitehurst, G. J. (1998). Relative efficacy of parent and teacher involvement in a shared-reading intervention for preschool children from low-income back grounds. Early Childhood Research Quarterly, 13, 263-290.

Martini, F., \& Sénéchal, M. (2012). Learning literacy skills at home: Parent teaching, expectations, and child interest. Canadian Journal of Behavioural Science. 44(3), 210.

Marulis, L. M. \& Neuman, S. B. (2013). How Vocabulary Interventions Affect Young Children at Risk: A Meta-Analytic Review. Journal of Research on Educational Effectiveness, 6(3), 223-262.

Masataka, N. (2014). Development of reading ability is facilitated by intensive exposure to a digital children's picture book. Frontiers in Psychology, 5, 396.

Mayesky, M. (2008). Creative activities for young children. (9th Ed.) New York, NY: Delmar.

Merriam, S. B. (2009). Qualitative research: A guide to design and implementation. San Francisco, CA: Jossey-Bass.

Morgan, H. (2013). Multimodal children's e-books help young learners in reading. Early Childhood Education Journal, 41(6), 477-483.

Morrow, L. M. (2005). Literacy development in the early years: Helping children read and write. Boston: Allyn and Bacon.

Owens, R. E. (2012). Language development: An introduction (8th edn.). Upper Saddle River: Allyn \& Bacon.

Reich, S. M., Yau, J. C., Xu, Y., Muskat, T., Uvalle, J., \& Cannata, D. (2019). Digital or print? A comparison of preschoolers' comprehension, vocabulary, and engagement from a print book and an ebook. AERA Open, 5(3), 1-16.

Robin, B. R. (2008). Digital storytelling: A powerful technology tool for the 21st century classroom. Theory into Practice, 47(3), 220-228.

Roskos, K. A. Sullivan, S., Simpson, D. \& Zuzolo N. (2016). E-Books in the early literacy environment: is there added value for vocabulary development? Journal of Research in Childhood Education, $30(2), 226-236$.

Rudman, R., \& Titjen, F. (2018). Language development. Cambridge: Cambridge University Press. 
Sak, R., Tantekin-Erden F., \& Morrison, G. S. (2018) Preschool teachers' beliefs and practices related to child-centred education in Turkey. Education 3-13, 46 (5), 563-577,

Şahin-Sak, I. T., Tantekin-Erden F., \& Pollard-Durodola, S. (2018) Turkish preschool teachers' beliefs and practices related to two dimensions of developmentally appropriate classroom management, Education 3-13, 46 (1), 102-116,

Santrock, J. W., (2012). Yaşam boyu gelişim gelişim psikolojisi. [Developmental Psychology of Lifelong Development]. (Çev. Ed: Yüksel G) Nobel Yayıncılık, Ankara.

Saracho, O. N., \& Spodek, B. (2010). Parents and children engaging in storybook reading. Early Child Development and Care, 180 (10), 1379-1389.

Senechal, M., \& LeFevre, J. (2002). Parental involvement in the development of children's reading skill: A 5-year longitudinal study. Child Development. 73, 445-460.

Şahin, A. (2018). Atasözlerinin yaratıcı drama ile öğretilmesi. Electronic Turkish Studies. 13 (19), 16591668.

Şimşek, Z. C. (2017). Farkıı Kitap Okuma Tekniklerinin 48-66 Ay Grubu Çocuklarının Dil Gelişsimine Olan Etkileri. (Doktora tezi). Pamukkale Üniversitesi Eğitim Bilimleri Enstitüsü, Denizli.

Şirin, M. R. (2000). Çocuk edebiyatı. İstanbul: Çocuk Vakıf Yayınları.

Taner Derman, M., Ergişi Birgül, A., \& Şahin Zeteroğlu, E. (2019). Farklı tekniklerle sunulan Türkçe dil etkinliklerinin 48-60 aylık çocukların dil gelişimlerine etkisinin incelenmesi. Electronic Turkish Studies. 14(1), 667-680.

Tetik, G., \& Işıkoğlu Erdoğan, N. (2017). Diyaloğa dayalı okumanın 48-60 aylık çocukların dil gelişimine etkisi. Kastamonu Eğitim Dergisi, 25(2), 1-16.

Tompkins, G. E. (2003). Literacy in the 21st century (3rd ed.). Upper Saddle River, NJ: Merrill Prentice Hall.

Trostle, S., \& Hicks, S. J. (1998). The effects of storytelling versus story reading on comprehension and vocabulary knowledge of British primary school children. Reading Improvement, 35, 127-136.

Turgut, M. F. \& Baykul, Y. (1992). Ölçekleme teknikleri. Ankara: ÖSYM Yayınları.

Türkben, T. (2018). Ana dili eğitimi ve öğretimi sürecinde masalların çocuk gelişimine katkılarına ilişkin öğretmen görüşlerinin incelenmesi. Electronic Turkish Studies, 13(19), 1821-1841.

Varol, i., Âlâ, S. ve Eti, M. (2020). Okul öncesi eğitimde Türkçe etkinliklerinde kullanılan hikâye anlatım tekniklerinin çocukların dikkat süresi üzerine etkisi. Temel Eğitim Dergisi. 2(1), 26-39.

Wasik, B. A., Hindman, A. H., \& Snell, E. K. (2016). Book reading and vocabulary development: A systematic review. Early Childhood Research Quarterly, 37, 39-57.

Wesseling, P. B., Christmann, C. A., \& Lachmann, T. (2017). Shared book reading promotes not only language development, but also grapheme awareness in German kindergarten children. Frontiers in Psychology, 8, 364.

Whitehurst, G. J., \& Lonigan, C. J. (2001). Emergent literacy: Development from prereaders to readers. Handbook of Early Literacy Research, 1, 11-29.

Whitehurst, G. J., Arnold, D. S., Epstein, J. N., Angell, A. L., Smith, M., \&Fischel, J. E. (1994). A Picture book reading intervention in day care and home for children from low - income families. Developmental Psychology, 30, 679-689.

Wright, C.Z. \& Dunsmuir, S. (2019) The effect of storytelling at school on children's oral and written language abilities and self-perception. Reading \& Writing Quarterly, 35(2), 137-153.

Yabe, M., Oshima, S., Eifuku, S., Taira, M., Kobayashi, K., Yabe, H., and Niwa, S. (2018). Effects of storytelling on the childhood brain: near-infrared spectroscopic comparison with the effects of picture-book reading. Fukushima Journal of Medical Science, 64(3), 125-132.

Zembat, R. \& Zülfikar, S. T. (2006). An investigation of conversation and story telling activities used by preschool education teachers. Educational Science: Theory \& Practice, 6 (2), 602-608.

Zivan, M., \& Horowitz-Kraus, T. (2020). Parent-child joint reading is related to an increased fixation time on print during storytelling among preschool children. Brain and Cognition, 143, 105596. 


\section{Introduction}

\section{Extended Abstract}

The main purpose of this study is to reveal the book reading and storytelling techniques that early childhood education teachers employ and prefer in their Turkish activities and the reasons why these techniques are preferred. Although storytelling and reading books are similar practices, they are used for different purposes. Storytelling is a part of human cultural heritage that has been used since the beginning of spoken language. Reading books, on the other hand, is reading written material namely, works of children's literature, aloud to illiterate children for their enjoyment and comprehension. It is known that both storytelling and reading book practices affect children's language development in the early period of their lives, support early literacy skills, and have positive effects on their cognitive abilities such as attention and focus. The positive effects of storytelling and reading books on children ensure that these activities are preferred in early childhood education and included in regular daily Turkish language activities. In the preschool education program (MEB, 2013), activities such as reading picture books, interactive and shared reading, storytelling, completion, retelling, illustrating, and creating a new story are recommended. Early childhood education teachers' inclusion of different storytelling and reading techniques in Turkish language activities positively affects children's language development and literacy skills. In this context, identifying the techniques teachers use in their Turkish language activities and why they prefer these techniques will be useful in increasing the quality of these activities.

\section{Method}

A basic qualitative research model, which enabled the researchers to examine the storytelling and book reading practices of early childhood teachers, their preferences, and the reasons for these preferences, was used in this study. 91 early childhood education teachers, determined by using convenience sampling, who worked in various provinces and districts across Turkey, participated in the study. The data collection tool and the consent form for participation in the research were created via Google survey. The data were collected using the 'Story Telling and Book Reading Form' developed by the researchers. The first part of the form consisted of 7 open-ended questions, eliciting teachers' personal information. In the second part, 9 items were used to ask teachers to rank the storytelling and reading techniques that they used and preferred. In those items, the teachers were offered a total of 9 reading and storytelling techniques, including reading techniques (traditional, interactive, and digital reading) and storytelling techniques (story cards, puppets, flannel board, pantomime, impersonation, and storytelling only with their voices (without any outside tools). The teachers were asked to rank each of these techniques one by one in order to determine the techniques preferred by them in general, the techniques that they thought supported children's learning, and techniques that children preferred the most. In the third part, open-ended questions were asked to allow the teachers to explain what the most preferred and least preferred storytelling and book reading techniques were and their preference reasons for their choices. The obtained data were analyzed by the content analysis method. At the end of the analysis process, two basic themes were formed. These were (1) reading and storytelling techniques used by the teachers, and (2) the teachers' reasons for using these techniques.

\section{Result and Discussion}

The findings of this study may be summarized under three general headings. Firstly, it was found that the teachers used traditional reading and storytelling techniques using only their voices (without any outside tools) more frequently than other techniques in Turkish language activities. The teachers' reasons for preferring traditional reading and storytelling with only their voices were these techniques' being fast, easy, economical, and not requiring much preparation. The teachers stated that even if they were unprepared, they made use of the books in their classes or schools for traditional reading and they could avoid negative consequences such as distraction and noise using both techniques even when they practiced those in large groups. The teachers also stated that although 
these techniques were directly relevant to the learners' age group, it was important to visually support young children because without visual material their attention span in those activities was limited.

Secondly, the research results revealed that teachers practiced and preferred interactive and digital-book reading less frequently. The teachers stated that digital reading was like 'watching cartoons'. Therefore, they used it less frequently. One recommendation regarding this finding would be to increase the knowledge and experience of early childhood education teachers on digital reading.

Thirdly, there appeared differences among the techniques teachers used in their classrooms, those that they and their young learners preferred, and those that they thought would support children's learning the most. Interactive reading, which is one of the techniques on which the differences of opinion was observed, was considered to be a reading technique that was believed to support learning the most and was preferred by children. However, it appeared less frequently in the practices and preferences of the teachers.

It was emphasized that traditional reading and storytelling techniques without any outside tools were used more frequently in teachers' practices, and that these techniques were easy to use, quick, and could be used with large groups. On the other hand, considering that children will gain different benefits from the implementation of different reading and storytelling techniques, a recommendation was made to include techniques such as interactive reading, pantomime, flannel board, and figures more frequently because these techniques would allow children to participate more actively. The teachers who participated in the study also stated that they experienced classroom management problems while practicing those techniques, especially during the implementation of animation-based techniques such as pantomime or impersonation; they felt inadequate in the implementation of those techniques because they did not have training in them and they lost control of their classes for that reason. Due to this, it would be beneficial for early childhood education teachers to receive training that would teach them how to use story reading and storytelling techniques effectively. 